\title{
MYRMECOPHILUS FUSCUS STALLING, 2013: NEW FOR THE FAUNA OF CROATIA (ORTHOPTERA: MYRMECOPHILIDAE)
}

\author{
Thomas Stalling ${ }^{1}$, Anton Gjeldum ${ }^{2}$, \\ Tino Milat ${ }^{3} \&$ Marko Pavlović ${ }^{4}$
${ }^{1}$ Möndenweg 26, 79594 Inzlingen, Germany (stalling@gmx.de); ORCID ID: 0000-0003-2734-4922
${ }^{2}$ City of Split, Obala kneza Branimira 17, HR-21000 Split, Croatia (agjeldum@gmail.com)
${ }^{3}$ Natural History Museum, Kolombatovićevo šetalište 2, HR-21000 Split,
Croatia (tino.milat@prirodoslovni.hr)
${ }^{4}$ Elementary School Vidovec, Školska ulica 4, 42005 Vidovec,
Croatia (marko09.pavlovic@gmail.com)

Stalling, T., Gjeldum, A., Milat, T. \& Pavlović, M.: Myrmecophilus fuscus Stalling, 2013: new for the fauna of Croatia (Orthoptera: Myrmecophilidae). Nat. Croat., Vol. 30, No. 1, 257-261, 2021, Zagreb.

The occurrence of the ant cricket Myrmecophilus fuscus Stalling, 2013 in Croatia is reported in this study. The first evidence of $M$. fuscus from Croatia comes from Solin, Split-Dalmatia region. Both adults and nymphs of this species were found in ant nests of Crematogaster scutellaris (Olivier, 1791) in dead wood of pine forests. The identification of M. fuscus is discussed and photographs of this species are presented.

Key words: Dalmatia, distribution, Europe, faunistics, myrmecophiles

Stalling, T., Gjeldum, A., Milat, T. \& Pavlović, M.: Myrmecophilus fuscus Stalling, 2013: nova vrsta za faunu Hrvatske (Orthoptera: Myrmecophilidae). Nat. Croat., Vol. 30, No. 1, 257-261, 2021, Zagreb.

Ovaj rad izvještava o nalazu mravoljupca, Myrmecophilus fuscus Stalling, 2013. u Hrvatskoj. Nalaz ove vrste iz Solina prvi je nalaz M. fuscus iz Hrvatske. Odrasle jedinke i nimfe ove vrste pronađene su u gnijezdima mrava Crematogaster scutellaris (Olivier, 1791) u mrtvom drvetu u borovoj šumi. U radu se raspravlja o identifikaciji $M$. fuscus te su priložene fotografije ove vrste.

Ključne riječi: Dalmacija, rasprostranjenost, Europa, faunistika, mravoljupci

Ant crickets (genus Myrmecophilus Berthold, 1827) are small insects known to live in ant nests, mostly as kleptoparasites (Schimmer, 1909; Wetterer \& Hugel, 2008). The genus Myrmecophilus has an almost cosmopolitan distribution. To date, there are 10 known species in Europe and 63 species worldwide (Cigliano et al., 2020; Hsu et al., 2020). So far, only two species have been recorded in Croatia: Myrmecophilus hirticaudus Fischer von Waldheim, 1846 on the island of Cres (Stalling \& Birrer, 2013) and Myrmecophilus myrmecophilus (Savi, 1819) in Split (BACCETTI, 1992). The records of other Myrmecophilus species are omitted in the checklist of Croatian crickets and grasshoppers due to lack of evidence (Skejo et al., 2018). 


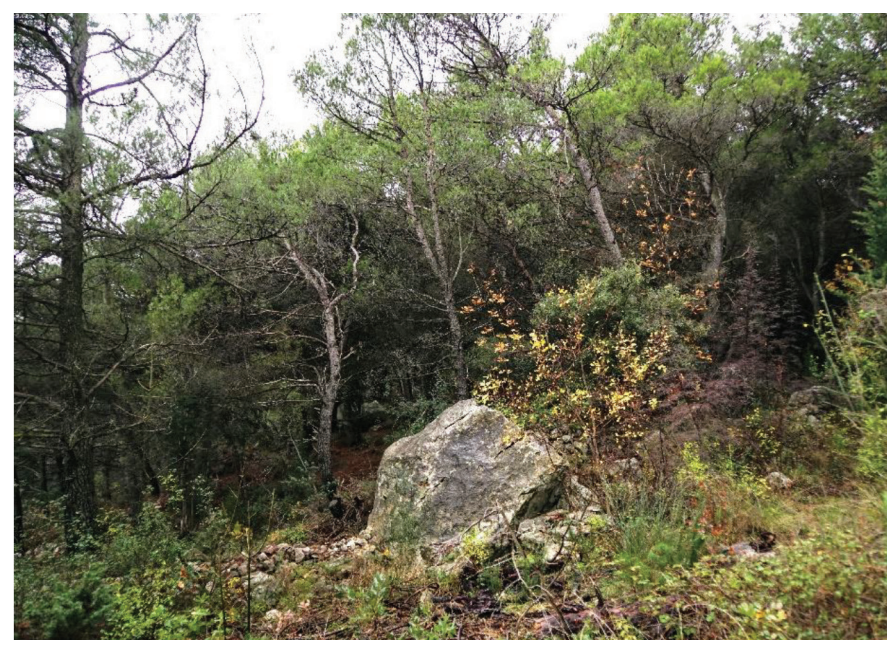

Fig. 1. Habitat of Myrmecophilus fuscus. November 2020, Split, Croatia (Photo: A. Gjeldum)

In November 2020, Anton Gjeldum and Tino Milat checked ant nests for the presence of Myrmecophilus crickets in the surroundings of Split, Split-Dalmatia region, Croatia. The habitat is characterised by semi-open Aleppo pine forest (Pinus halepensis) (Fig. 1). Ant nests were found in the trunks of dead Aleppo pines. After Myrmecophilus specimens were caught on cotton gauze by shaking the trunks, they were preserved in $70 \%$ ethanol and subsequently pinned and dried. The criteria of STALLING (2013) were followed to perform specimen identification together with direct comparison with specimens of the type series of Myrmecophilus fuscus. Subsequently, the ants were identified according to the criteria of ANTWIKI (2020).

A total of 11 M. fuscus specimens were collected at a site close to Solin (43.566032, 16.495805), Split-Dalmatia region, Croatia, at about $345 \mathrm{~m}$ above sea level. A single adult male was caught on 16 November 2020, while two adult females, five adult males and three male nymphs were found in a nest of Crematogaster scutellaris (Olivier, 1791) on 22 November 2020, leg. Anton Gjeldum and Tino Milat, coll. Thomas Stalling (Figs. 2, 3).

The records obtained during this study are the first for Croatia and represent the easternmost record of this species, whose distribution has so far been known from Spain through France and Malta to Italy (Stalling, 2015, Stalling et al., 2015) (Fig. 4). C. scutellaris is a typical host ant species along with Lasius ants (Fabricius, 1804) (Stalling et al., 2015). M. fuscus differs from the two other Myrmecophilus species in Croatia by the following characteristics (Stalling, 2013; Stalling \& Birrer, 2013): the coloration is dark ochreous with pale ochreous posterior margins of the pronotum, mesonotum and tergites 1-3 (Fig. 3); (uniformly dark brown coloration in M. hirticau$d u s$, pale ochreous with no or inconspicuous pale posterior margins of pronotum, mesonotum, and tergites in M. myrmecophilus); the subgenital plate in females is clearly emarginated (rounded in M. myrmecophilus); the first segment of the basitarsus has two subapical spines (three in $M$. hirticaudus). This species might have been overlooked in the past due to its cryptic lifestyle and difficult identification. We can assume that in the future $M$. fuscus will be found in other regions of Croatia that have a Mediterranean climate. 


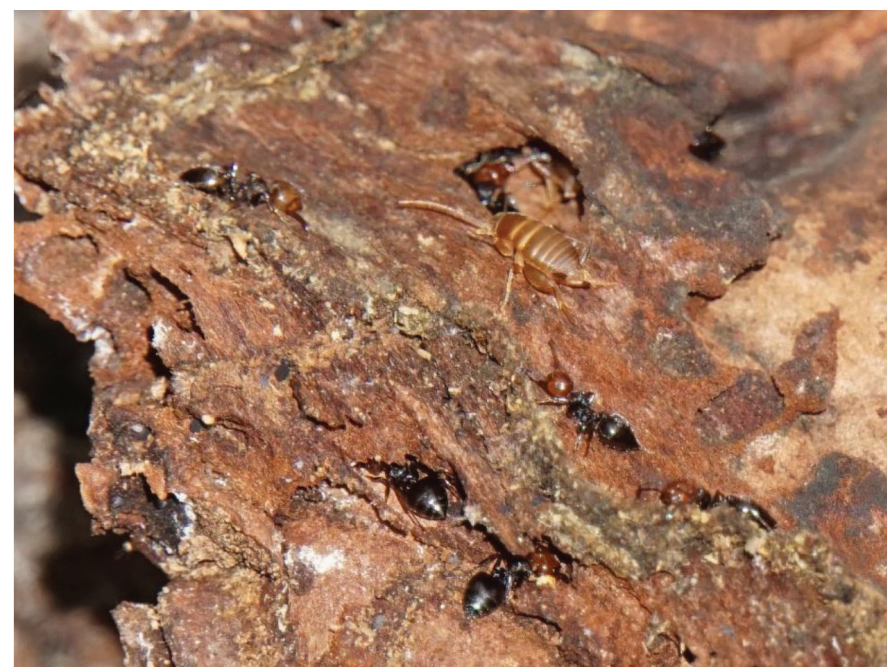

Fig. 2. Myrmecophilus fuscus, adult female, with its host ant Crematogaster scutellaris. November 16th 2020, Split, Croatia (Photo: A. Gjeldum)

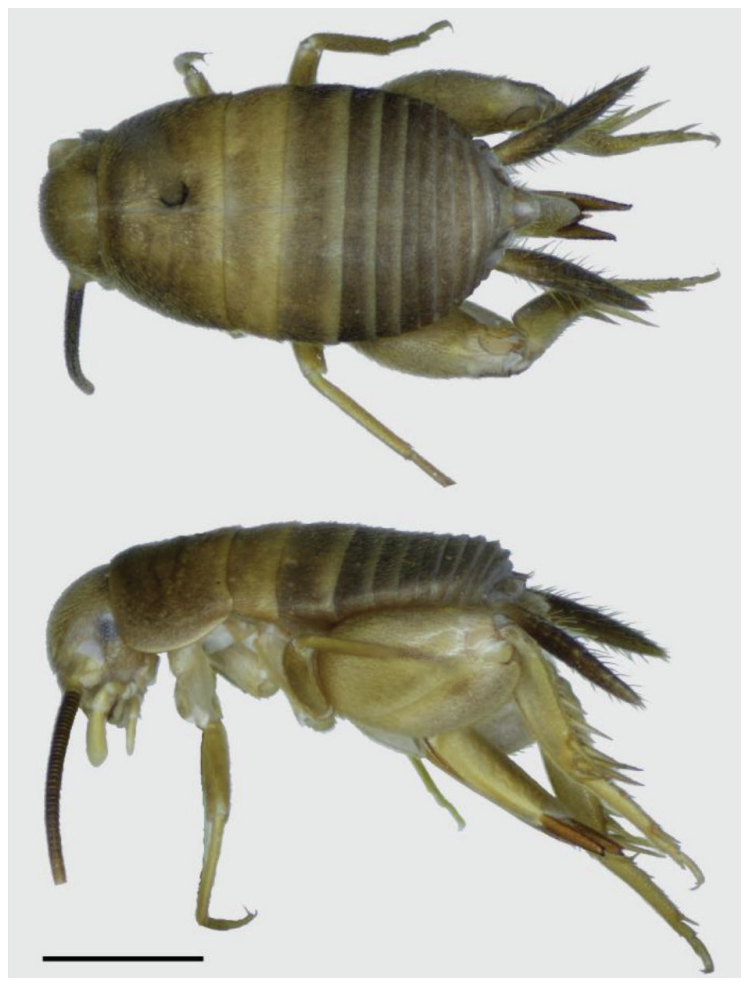

Fig. 3. Myrmecophilus fuscus, adult female. November 22th 2020, Split, Croatia. Dorsal (top) and lateral (bottom) view of a preserved specimen. Scale bar $1 \mathrm{~mm}$ (Photo: T. Stalling) 


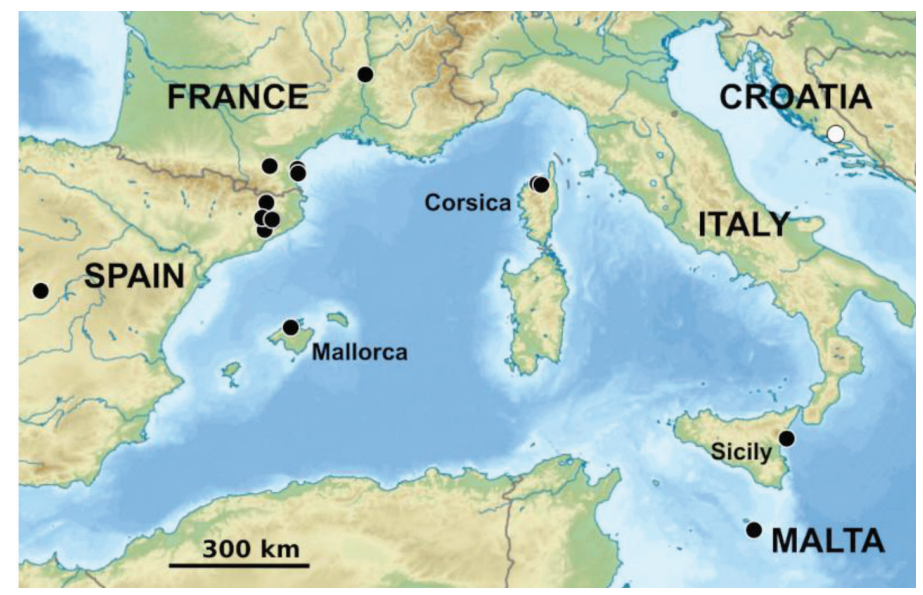

Fig. 4. Known distribution of Myrmecophilus fuscus. Black dots: previously published records; white dot: new finding from Croatia. The map is based on the map by Nzeemin, (c) GNU Free Documentation License.

\section{ACKNOWLEDGEMENTS}

We are grateful to Josip Skejo for his help in introducing the finders and Thomas Stalling to each other.

Received February 10, 2021

\section{REFERENCES}

AntWiki, 2020: Key to West European Crematogaster species. [02.12.2020]. Homepage: https:/ /www. antwiki.org/wiki/Key_to_West_European_Crematogaster_species.

BАСсетті, B., 1992: Notulae orthopterologicae. 50. Su alcuni ortotteroidei del Mediterraneo orientale. Fragmenta Entomologica, 23 (2), 247-276.

Cigliano, M. M., Braun, H., Eades, D. C. \& Otte, D., 2020: Orthoptera Species File Online, Version 5.0/5.0. [10.11.2020]. Homepage: http:/ /Orthoptera.SpeciesFile.org.

Hsu, P.-W., Hugel, S., Wetterer, J. K., Tseng, S.-P., Ooi, C.-S. M., Lee, C.-Y. \& Yang, C.-C. S., 2020: Ant crickets (Orthoptera: Myrmecophilidae) associated with the invasive yellow crazy ant Anoplolepis gracilipes (Hymenoptera: Formicidae): evidence for cryptic species and potential co-introduction with hosts. Myrmecological News 30, 103-129.

Schimmer, F., 1909: Beitrag zu einer Monographie der Gryllodeengattung Myrmecophila Latr. [Contribution to a monograph of the gryllid genus Myrmecophila Latr.]. Zeitschrift für Wissenschaftliche Zoologie 93, 409-534. (in German)

Skejo, J., Rebrina, F., SzÖvényi, G. \& Puskás, G, 2018: The first annotated checklist of Croatian crickets and grasshoppers (Orthoptera: Ensifera, Caelifera). Zootaxa 4533(1), 1-95.

Stalling, T., 2013: A new species of ant-loving cricket from Mallorca, Balearic Islands, Spain (Orthoptera: Myrmecophilidae). Graellsia 69(2), 153-156.

Stalling, T., 2015: New records of the ant-loving cricket Myrmecophilus fuscus Stalling, 2013 from the Mediterranean Basin (Orthoptera: Myrmecophilidae). Articulata 30, 105-108.

Stalling, T. \& Birrer, S., 2013: Identification of the ant-loving crickets, Myrmecophilus Berthold, 1827 (Orthoptera: Myrmecophilidae), in Central Europe and the northern Mediterranean Basin. Articulata 28(1/2), 1-11.

StAlling, T., Espadaler, X. \& CARRÓN, N. O. Z., 2015: First record of the ant-loving cricket Myrmecophilus fuscus Stalling, 2013 (Orthoptera: Myrmecophilidae) in mainland Spain. Sociobiology 62(4), 481-483.

Wetterer, J. K. \& Hugel, S., 2014: First North American records of the Old World Ant Cricket Myrmecophilus americanus (Orthoptera, Myrmecophilidae). Florida Entomologist 97, 126-129. 


\title{
SUMMARY
}

\section{Myrmecophilus fuscus Stalling, 2013: new for the fauna of Croatia (Orthoptera: Myrmecophilidae)}

\author{
T. Stalling, A. Gjeldum, T. Milat \& M. Pavlović
}

Ant crickets (genus Myrmecophilus Berthold, 1827) are small myrmecophilous insects. In Croatia, only Myrmecophilus hirticaudus Fischer von Waldheim, 1846 and Myrmecophilus myrmecophilus (Savi, 1819) have been known so far. In November 2020, Myrmecophilus fuscus Stalling, 2013 was found in a semi-open Aleppo pine forest close to Split, Split-Dalmatia region, Croatia. This is the first evidence of M. fuscus from Croatia and represents the easternmost record of this species. The species lives in ant nests of Crematogaster scutellaris (Olivier, 1791) in dead wood of pine forests. 